\title{
Em busca da justiça: o processo de criminalização do racismo no Rio de Janeiro a partir de um estudo quantitativo sobre as bases de dados do ISP - 2007-2010s
}

Luciane Silva*

Lygia Costa**

\section{Resumo}

A partir da Constituição Federal de 1988, atos decorrentes de preconceito de raça e cor tornaram-se passíveis de punição. Este artigo evidencia as tensões cotidianas decorrentes de registros de ocorrência de atos considerados discriminatórios, no Estado do Rio de Janeiro, a partir de registros feitos em delegacias e, posteriormente, agrupados pelo ISP (Instituto de Segurança Pública), entre 2007 e 2010.0 objetivo deste artigo é apresentar alguns dados sobre a distribuição dos registros referentes a crimes envolvendo preconceito de cor no território fluminense. Analisaremos o perfil dos denunciantes, a relação existente entre denunciantes e supostos agentes discriminatórios, os principais locais de ocorrência do ato discriminatório e também como algumas dessas variáveis se distribuem territorialmente.

\section{Palavras-chave}

Criminalização. Desigualdade racial. Atos discriminatórios.

\section{Abstract}

Since the promulgation of the Brazilian Constitution in 1988, acts of race or color discrimination became punishable. Drawing from records made at police stations and afterwards grouped by the Public Security Institute, between 2007 and 2010, this paper highlights everyday tensions resulted from registering complaints about acts considered discriminatory in the state of Rio de Janeiro. The purpose is to present data on the distribution of records relating to crimes

\footnotetext{
* Luciane Silva é chefe do Laboratório de Estudos da Sociedade Civil e do Estado, pesquisadora do Núcleo de Estudos de Exclusão e da Violência - NEEV e professora associada Universidade Estadual do Norte Fluminense Darcy Ribeiro - UENF. E-mail: lucianecoltrane@gmail.com.

** Lygia Costa é professora e pesquisadora da Escola de Administração Pública e Empresas EBAPE / Fundação Getúlio Vargas - FGV; e pesquisadora do Observatório das Metrópoles / Instituto de Pesquisa e Planejamento Urbano Regional - IPPUR. E-mail: lygia.costa@fgv.br.
} 
involving color discrimination in the state of Rio de Janeiro. We analyzed whistleblowers profiles, the relationship between complainants and alleged discriminatory agents, most common locations of occurrence for discriminatory acts, and also how some of these variables are distributed within the state area.

\section{Keywords}

Criminalization. Racial inequality. Discriminatory acts.

\section{Introdução}

Pesquisar as formas de interação social resultantes da criminalização do racismo no texto Constitucional de 1988 possibilita uma reflexão sobre as tensões atuais nas interações cotidianas entre brancos e não brancos no Brasil.

A população africana trazida ao Brasil em regime de escravidão experienciou ao longo de sua história em solo brasileiro as agruras, torturas e crueldades próprias do sistema escravocrata. Ao longo destes anos, a administração dessas populações ocupou um lugar central nas decisões governamentais (do Império à República).

Na Constituição de 1824, o escravo possuía um estatuto jurídico, no qual era a um tempo pessoa e, a outro, mercadoria. Da mesma forma, essa Constituição, ao garantir aos "libertos" a condição de cidadãos brasileiros, não apagara o significado do termo: "libertos" são os que, tendo nascido escravos, de alguma forma obtiveram a liberdade (CABRAL, 1974, p.70). $\mathrm{E}$, mesmo nesses casos, devemos observar que o senhor poderia revogar a alforria, caso desejasse. A condição do liberto não tinha garantias, estava vinculada ao desejo do senhor.

A Constituição de 1890 serve como exemplo do "problema das raças" para o Brasil. Proclamada a República, como resolver o problema dos negros alforriados? Ao mesmo tempo em que o racismo científico justificava o lugar dos escravos libertos em uma sociedade em transformação, o ideal do branqueamento possibilitaria a administração das populações que deveriam compor a nação. O decreto $n^{\circ} 528$, de 28 de junho de 1890, que regulamentava a introdução de imigrantes no Brasil, proibiu a entrada de africanos e asiáticos no país. 
As discussões em torno da Constituição de 1934 acirraram as discussões sobre a condição desejada pelo país quanto à sua composição racial: era necessário vetar a entrada de grupos africanos e asiáticos (especialmente japoneses). Um dos mais ardorosos defensores desse controle, o médico Miguel Couto, apresentou uma emenda que proibia a entrada de africanos e estipulava uma proporção de $5 \%$ para asiáticos, além de proibir os Estados de contratos independentes deste artigo (GERALDO, 2009, p.182).

Observando essas três Constituições anteriores a 1988 (considerando que, em 1943, Vargas seguiu incentivando a imigração europeia), é possível argumentar que a Constituição Cidadã representou uma efetiva transformação do estatuto jurídico que o negro ocupara até então no Brasil.

Uma das grandes dificuldades encontradas nas pesquisas sobre a temática racial no Brasil, especificamente demonstrações de preconceito com base em percepções sobre cor/raça, reside no difícil acesso aos casos sobre o tema. Considerando a permanência do mito da democracia racial como central às representações de parte da população sobre a convivência harmoniosa entre diferentes "raças" ou grupos étnicos, pesquisar casos cotidianos esbarra não raras vezes em um discurso de que estamos "importando um problema". A demonstração dos registros em delegacias evidencia que as interações entre esses grupos sofreram importantes alterações após a Constituição de 1988. A politização das formas de classificação dos não brancos, ou seja, a mudança na forma de declaração para o IBGE, por exemplo, nos leva a supor que existem importantes mudanças nas formas de representação dos não brancos quanto à cor. A não aceitação de piadas ou mesmo de xingamentos próprios de um momento anterior à criminalização do racismo pode ser medida pelo número de ocorrências aqui analisadas.

Este artigo apresentará o resultado de pesquisa realizada a partir dos dados do Instituto de Segurança Pública (ISP-RJ) sobre ocorrências registradas nas delegacias do Rio de Janeiro entre os anos de 2007 e 2010. É importante ressaltar que o banco de dados original foi totalmente reformulado para atender aos interesses de pesquisa. Produzir dados a partir de registros policiais e processos judiciais é mais um obstáculo à construção de indicadores sobre racismo no cotidiano brasileiro. Considerando a posição dos operadores do Direito no Brasil em relação ao tema, enfrentamos não só a dificuldade de acesso aos dados, mas também a oposição explícita de parte desses operadores no processo da pesquisa. Há uma compreensão explicitada em falas de que "este é um problema menor frente aos outros".

Na primeira sessão, apresentaremos uma discussão sobre a relação entre 
a construção das classificações sobre raça/cor no Brasil e como a esfera jurídica preocupou-se com a população negra, vista como um entrave à consolidação do projeto de nação. A segunda sessão apresenta a construção e análise das ocorrências registradas. São gráficos simples, em um primeiro momento, sobre o número de ocorrências, sexo e idade das vítimas. Interessa particularmente os dados sobre profissão e local de ocorrência dos casos.

A conclusão deste artigo retoma algumas observações de Costa Pinto, ressaltando que a pesquisa sobre esse tema no Brasil colabora com a reelaboração (ou desconstrução) do mito de nossa convivência harmoniosa. Considerando nosso "preconceito de ter preconceito", como afirmara Florestan Fernandes, essas pesquisas possibilitam repensar o cotidiano racial e os possíveis desdobramentos postos como horizonte no século XXI. A criminalização do racismo, a partir da Constituição de 1988, possibilitou a discussão aberta de situações diversas: piadas em ambiente escolar, ofensas pelas redes sociais, recusas de atendimento em estabelecimentos comerciais, abordagens policiais, por exemplo. Situações anteriormente naturalizadas e agora registradas e passíveis de fornecer importantes problemas de pesquisa para aqueles interessados nessa temática.

\section{Cor e lei no Brasil}

Algumas interpretações sobre a convivência harmoniosa entre brancos e negros no Brasil poderão ser problematizadas com dados do cotidiano, complementando uma vasta bibliografia já existente sobre o tema da discriminação e da desigualdade social com base em grupos de cor. O estudo das tensões sociais já interessara a Costa Pinto em sua pesquisa sobre a situação do negro no Distrito Federal (Rio de Janeiro). Apontava o referido autor que as tensões representavam: a) uma fase de um processo em desenvolvimento, b) resultado de um conflito virtual ou potencial existente no fundo da situação social considerada e c) viria à tona, de diversos modos e em diversos graus de intensidade, sob a forma de "descargas de tensão" até que o conflito encontrasse meios de se "acomodar" e a tensão fosse contida, ou atingisse um desfecho sob a forma de crise aberta e declarada (PINTO, 1953, p.272).

É importante que se observe a primeira premissa, pois esta faz referência à mobilidade social dos negros como possibilidade de instauração de tensões sociais. Diferem das relações descritas por Freyre, nas quais o negro teria 
se adaptado relativamente bem ao cativeiro, relações de apadrinhamento e convivência afetiva nas quais estava ausente a competição social aberta entre diferentes grupos de cor.

Em relação à segunda premissa, antes da lei atual, o ato de demonstrar preconceito em relação a alguém com base em sua cor era contravenção (Lei Afonso Arinos de 1951). Existiria o conflito, mas as situações não eram sequer registradas. Dificilmente alguém iria até uma delegacia prestar queixa porque foi chamado de "macaco" ou teve seu cheque recusado em uma loja. O estímulo para o registro após 1988 reside não só na possibilidade de prisão do autor, como também na possibilidade de indenização à vítima. Acima de tudo, recorrer à justiça para fazer a queixa possibilita a publicização de uma situação reconhecida como injusta pelo indivíduo que não aceita mais determinadas piadas, ofensas, opiniões e formas de tratamento.

Antes da apresentação e discussão dos dados, é importante observar que, desde a criminalização dessas práticas, em 1988, o acesso à justiça nos casos de racismo instaura uma arena de conflitos entre denunciantes e operadores do Direito, desde o momento de registro na delegacia até as instâncias superiores de julgamento. Um dos exemplos mais eloquentes quanto ao tema é o caso Simone A. Diniz. Em 1997, Simone foi recusada para o preenchimento de uma vaga de doméstica, pois a empregadora exigira em anúncio publicado na Folha de São Paulo "de preferência branca". Após registro na delegacia e inquérito, o promotor solicitou o arquivamento junto ao juiz alegando não haver verdadeira intenção de discriminar alguém por causa da cor e/ou raça (BARBOSA, 2011).

O caso foi arquivado em abril de 1997, e sem possibilidade de conseguir uma resposta da justiça brasileira, Simone recorreu à Comissão Interamericana de Direitos Humanos, que condenou o Estado Brasileiro por reconhecer que não foi assegurado o acesso à justiça. Em texto, a OEA recomendou um melhor treinamento dos funcionários da Justiça e da polícia, a fim de evitar práticas discriminatórias durante investigações dessa natureza.

O desenvolvimento do processo dependerá do interesse da vítima em representar contra o acusado em um período de tempo predeterminado pela Justiça (seis meses). Foram consultados 15 processos de decisão em Câmaras Cíveis da cidade do Rio de Janeiro entre 2005 e 2010. Esses dados estão disponíveis no site do Tribunal de Justiça do Rio de Janeiro.

Essas informações não constituem uma amostra metodologicamente rigorosa, serão apenas apresentadas com o objetivo de demonstrar alguns dados do cotidiano envolvendo o conflito racial e que conseguem alcançar 
instâncias superiores de julgamento. Os termos que evidenciam o conflito são comuns aos 15 processos: "foi submetido a humilhações", "foi atingido em sua dignidade", "atingido em sua honra". A argumentação jurídica visa, nesses casos, ao direito da pessoa, que, ofendida em sua honra, "em virtude de sua cor”, merece uma reparação do dano. Essa reparação, no Brasil, tem ocorrido na forma de indenizações que podem variar quanto ao valor. Em geral, é na esfera civil e não penal que acontecem os casos de condenação. Nos processos consultados, apenas seis obtiveram valores indenizatórios que variaram entre $R \$ 2.000$ reais e $R \$ 10.000$ reais, sendo este último valor referente a um processo por constrangimento em banco quanto à porta giratória e ação dos seguranças. $\mathrm{O}$ valor elevado teve sua justificativa com base no constrangimento da vítima, sendo a cor da pele complementar à argumentação.

Quanto às ofensas, incluem desde insultos onde há nomeação do outro (GUIMARÃES, 2001) sua negrinha; situações de impedimento de entrada em estabelecimentos comerciais e de lazer; ofensas ao grupo racial ao qual pertence a vítima, negro burro, vocês deveriam estar no tronco, só poderia ser coisa de preto, preto antigamente não entrava nem na sala da sinhá, hoje vem para o mercado com 10 reais e quer comprar 100 reais, até situações de preterimento para cargos de trabalho e transferências de setor consideradas injustas. Um caso que foge à regra, mas é certamente emblemático: um policial militar processa uma empresa jornalística ao sentir-se exposto por ter sido fotografado revistando um táxi onde estariam dois ocupantes não brancos. Apesar de reconhecer que, em alguns casos, os policiais militares agem com abuso em relação a "negros e pobres", o policial militar teve sua causa reconhecida, pois, $a$ exposição de sua imagem poderia prejudicá-lo em sua vida e em seu trabalho. Os locais em que esses conflitos aconteceram demonstram a diversidade das situações de conflito: transporte coletivo, lojas de roupas, universidades privadas, secretarias de Estado, empresas de comunicação, bancos, hospitais estaduais, supermercados, condomínios, clubes.

Em entrevista com um delegado da $5^{\text {a }}$ DP, algumas questões foram observadas: a primeira demonstra a seleção dos casos que serão registrados, o grau de arbítrio do policial e como sua compreensão "dos fatos" será decisiva para que a queixa seja acolhida. Em sua opinião,

“(...) tem que observar, o que é esta ofensa, será que é realmente uma ofensa discriminatória de raça? Ou é uma ofensa direta a pessoa? Pode ser especificamente aquela pessoa e não com o 
caráter geral de raça. Aqui em nossa delegacia, a verbalização onde há presença de insulto verbal é toda transcrita. Aí você vê que existe um conteúdo realmente discriminador. Mas é preciso pesar, avaliar direito em que situação vai enquadrar a pessoa, às vezes não tem nada a ver; é preciso ter um bom senso, fazer uma avaliação sobre o que é dito, antes de ir logo escrevendo o que foi dito".

Uma das declarações do entrevistado - que melhor ilustra as dificuldades para definição de um caso como discriminatório ou de injúria racial demonstra algo que está presente no cotidiano brasileiro: as palavras dependerão da situação, ambiente e relação de quem as proferiu com o alvo das mesmas:

“Existem casos, existem. 'Negão, crioulo', muitas vezes não tem o aspecto ofensivo - como, 'seu filha da puta' você não está ofendendo a mãe dele, o sentido hoje deste termo não é ofender a dignidade da mãe do sujeito, você está ofendendo o caráter dele, como uma pessoa que não teria caráter, não teria dignidade. Então muitas vezes o termo 'crioulo, negão', é mais uma injúria que exatamente uma discriminação”.

Por último, cabe destacar a posição do delegado quanto aos casos, que pode ser estendida a grande parte dos juízes e desembargadores em suas argumentações sobre discriminação e racismo no Brasil:

“O Brasil é um país tranquilo, todo mundo professa sua religião, vai na igreja, vai no centro espírita, eventualmente tem algum caso - mais pontuais, geralmente de evangélicos com umbandistas e até com a própria religião católica. Alguns, algumas pessoas são assim. O perigoso mesmo, terrorista, não existe aqui, você convive, italiano com árabe com judeu, todo mundo respeita. Então, nós temos esta tranquilidade e a população realmente ela tem um respeito pelo seu próximo, o brasileiro é muito apegado, se apega muito, ao amigo, ao vizinho, ao porteiro".

Suas percepções não deixam dúvida: para ele, o racismo, esses atos, são “casos isolados", estranhos à personalidade "cordial” do brasileiro. 


\section{Metodologia: Os registros em delegacias do Rio de Janeiro}

Por que criminalizar atos considerados racistas em um momento histórico em que a própria noção de raça perdia seu sentido nos debates científicos mundiais, sendo combatida de forma veemente? Por que o Brasil, após anos de negação quanto à existência de preconceito, resolveria criminalizar atitudes racistas como inafiançáveis e imprescritíveis?

Uma das interpretações mais comumente aceitas faz referência às pressões sociais do Movimento Negro $^{1}$, que já vinha fazendo essa denúncia há décadas, e o reconhecimento do racismo no texto constitucional seria resultado de um longo período de pressão da sociedade civil e não apenas resultado do reconhecimento do Estado em relação ao problema dos negros nas relações cotidianas de trabalho, consumo, lazer, ensino, religiosas (para citar as mais frequentes).

A dinâmica resultante da correlação de forças entre Estado, movimentos sociais e produção intelectual (no caso do movimento negro, os trabalhos de Florestan Fernandes foram fundamentais para formulação da luta política) possibilitou que a Lei 7.716 fosse promulgada e complementada pela Lei Caó.

Para a pesquisa sociológica, os registros em delegacias possibilitam a problematização de conflitos cotidianos que dificilmente seriam captados em pesquisa com uso de técnicas de entrevista, uma vez que o preconceito raramente é explicitado em situações de pesquisa.

Nesse sentido, acessamos os dados dos registros de injúria por preconceito do Instituto de Segurança Pública do Rio de Janeiro (ISP), que foram liberados a partir de negociações que exigiram documentos formais. Analisaremos os registros efetuados, pelas vítimas, em delegacias do Rio de Janeiro entre os anos de 2007 a 2010. As principais informações apresentadas farão referência à idade (com data de nascimento, sexo, grau de escolaridade, relação com o agressor, cor da vítima, estado civil, ocupação, naturalidade, local da ocorrência (com detalhes sobre os estabelecimentos).

Com relação à cor/raça o ISP segue a classificação oficial do IBGE (Instituto Brasileiro de Geografia e Estatística), e os casos são registrados

\footnotetext{
${ }^{1}$ Para mais detalhes, ver: Michael Hanchard. Orfeu e o Poder, Movimento Negro no Rio e São Paulo (1945-1988), EdUerj, 2001.
} 
de acordo com as características dadas pela pessoa com base nas seguintes opções: brancos, negros, pardos, indígenas e amarelos.

Os conflitos envolvendo casos relacionados a preconceito e discriminação por cor e/ou raça ocorrem geralmente a partir de situações nas quais são empregados insultos verbais, como apontou pesquisa de Guimarães (2002), em delegacia de São Paulo, e Silva (2003), em delegacias do Rio Grande do Sul. Um dos maiores problemas com pesquisas desta natureza é o acesso ao dado (os boletins de ocorrência, processos, bancos de registros) e à precariedade com que ocorrem esses registros (pequenos erros de digitação, dados incompletos, omissões que detalhariam melhor o caso). Como afirma Pager (2006), é necessário que se lance mão do maior número de técnicas possíveis para alcançar respostas minimamente satisfatórias sobre o tema. Para este trabalho, serão apresentadas as principais tabelas que resultaram da análise quantitativa dos dados do ISP, além de alguns casos emblemáticos para compreensão do tratamento dado à questão pelo Judiciário.

O objetivo do trabalho nãoé questionar os limitesdo Direito Penal brasileiro enquanto instrumento de combate ao racismo. O que a criminalização tem possibilitado é a pesquisa de atos considerados racistas e preconceituosos como importante indicador das alterações das representações sociais sobre os negros, mestiços e mulatos na sociedade brasileira entre o fim do século XIX e este início do século XXI.

Além disto, a partir do perfil dos denunciantes, é possível inferir que um dos efeitos indiretos da lei é possibilitar a autodeclaração ativa, ou seja, dois processos são desnaturalizados: o primeiro, tão comum no Brasil, é acreditar que boa parte da população passaria por "morena", diluindo qualquer possibilidade de organização política com base racial. $\mathrm{O}$ segundo, tão frequente quanto o primeiro, faz referência à jocosidade própria das piadas, nomeações e xingamentos, encarados como parte da nossa cultura. $\mathrm{O}$ ato de deslocar-se até uma delegacia com a intenção de registrar uma situação na qual houve ofensa (injúria) demonstra como é importante observar esses dados. Não para medição da aplicação das penas, uma vez que a posição do Judiciário no Brasil é praticamente consensual na desconstrução dos casos registrados, que alcançam uma fase posterior como inquéritos.

Esses dados indicam que as relações cotidianas passam a ter em sua composição esta nova variável: a não aceitação da piada, do xingamento de última hora, da perseguição ou constrangimento público em função da cor. Exemplificando: certa tarde, segundo relatos de quem presenciou o fato, em uma das ruas principais do Leblon, bairro do Rio de Janeiro, um guardador 
de carros, ao ser ofendido pelo motorista, disse em alto e bom som: "O senhor sabia que racismo é crime?" Um pequeno número de pessoas que passava pelo local assistiu à situação, e o constrangimento do motorista foi visível: ele não esperaria que alguém em posição social inferior usasse de um discurso jurídico para reclamar um tratamento igualitário.

A lei brasileira que trata do racismo é a de 7.716, de 5 de janeiro de 1989, e a pena relacionada a esse tipo de crime no Brasil é inafiançável, e, uma vez registrado o fato em flagrante, o acusado vai direto para a cadeia e não tem direito a pagar fiança para aguardar o julgamento em liberdade. Mas isso ainda é raro acontecer no Brasil. O problema é que no Brasil muitas alegações de racismo jogam no terreno das suposições, e o réu acaba sempre tendo o benefício da dúvida, pois são acionadas inúmeras desculpas às quais as pessoas podem utilizar para eximir-se de qualquer acusação.

Pensando na realidade das denúncias consideradas racistas nas delegacias no Estado do Rio de Janeiro, objetivamos nesta pesquisa analisar a relação existente entre o crime de injúria por preconceito e a cor. O número total de casos analisados, nos microdados cedidos pelo ISP, de vítimas de injúria por preconceito foi de 3.773 casos entre os anos de 2007 e 2010, no Estado do Rio de Janeiro, mas tem-se consciência, entretanto, de que o número de casos pode ser maior. Quanto à cor, o ISP utiliza a seguinte classificação em relação à cor: brancos, negros e pardos.

Pelo Gráfico 1, mais de 50\% dos registros de ocorrência nos casos de injúria por preconceito no Estado do Rio de Janeiro concentraram-se no município do Rio de Janeiro entre os anos de 2007 e 2010. Por outro lado, apesar da oscilação em torno do número de registros anuais, observamos uma tendência no aumento percentual no conjunto das denúncias de injúria por preconceito nas outras áreas que abrangem o Estado: Baixada Fluminense, Municípios Metropolitanos e Municípios Não Metropolitanos.

Infelizmente, não temos como mostrar neste artigo qual o percentual de crimes denunciados punidos ou não como injúria por preconceito, mas podemos evidenciar se de alguma forma há preconceito de cor dada a cor da vítima nas delegacias do Estado conforme resultados de tabelas e gráficos nesta pesquisa.

O gráfico 1 apresenta a distribuição dos registros por municípios do Estado do Rio de Janeiro e não surpreende uma concentração dos registros na capital fluminense. Considerando não só o número de delegacias existentes nos municípios, mas também a sensibilidade jurídicos dos operadores, podemos inferir que a configuração dos conflitos é acolhida nesses espaços 
mesmo que esse dado não represente a resolução dos mesmos. Como dito anteriormente, indica sua existência no cotidiano urbano e serve como bússola para pesquisa sobre possíveis quadros gerais que colaborem na compreensão das atuais formas que assumem as tensões raciais no Brasil.

Gráfico 1 - Registros de ocorrência de injúria por preconceito no Estado do Rio de Janeiro entre os anos de 2007-2010

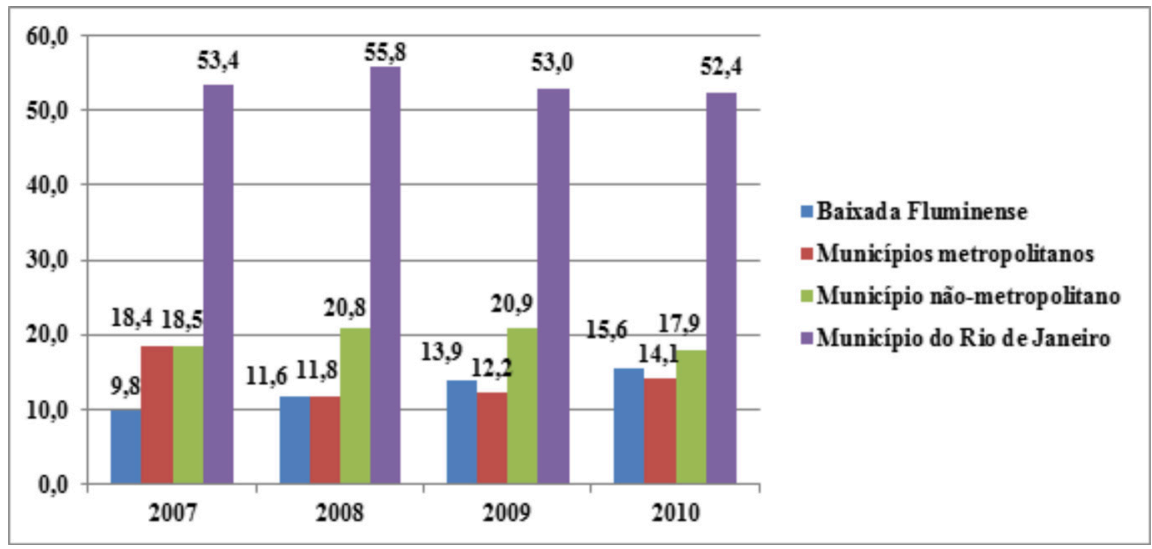

Fonte: ISP. Tabulado pelas autoras.

Observando o Gráfico 2, nota-se que o maior número de pessoas que foram vítimas de crime de injúria por preconceito, nas delegacias do Estado do Rio de Janeiro entre os anos de 2007 e 2010, está relacionado a homens e mulheres negros e pardos. Analisando os percentuais, nos referidos anos, dentro dos grupos de mulheres e homens, temos que negros e pardos foram responsáveis por cerca de, no mínimo, 80\%, e, no máximo, $90 \%$ das denúncias de injúria por preconceito nas delegacias do Estado. Esse dado começa a dar as primeiras pistas de que o crime de preconceito está fortemente correlacionado à questão da cor, e a identificação desse crime começa a se materializar em forma de denúncia, apesar do aumento do discurso antirracista e não preconceituoso da população brasileira. 
Gráfico 2 - Vítima segundo a cor e o sexo nos anos de 2007-2010

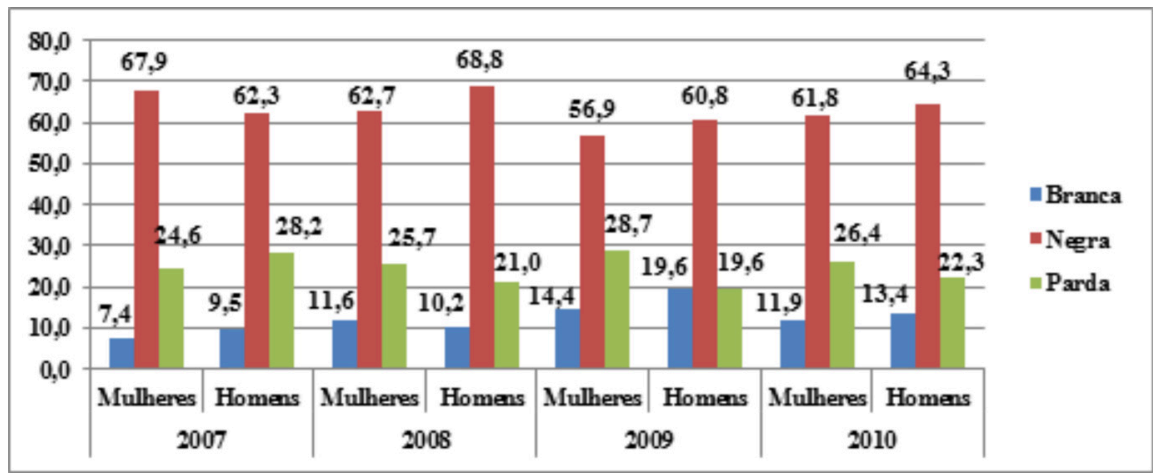

Fonte: ISP. Tabulado pelas autoras.

Pela Tabela 1, dentro das idades e entre os grupos de cor, observamos um percentual maior de vítimas de injúria por preconceito, sobretudo, negros. Em 2007, por exemplo, analisando os percentuais de destaque, observamos que, nas idades de 0 a 14 anos, o número de vítimas negras foi 23.1 vezes maior que o de brancos e 2.8 vezes maior que o de pardos; e pardos vítimas, com relação a brancos, foi 8.0 vezes maior. E na coorte de idade de 45 a 54 anos, o número de vítimas negras foi 9.0 vezes maior que o de brancos e 4.3 vezes maior que o de pardos; por outro lado, pardos vítimas, nesta mesma coorte foi 2.1 vezes maior que brancos. Em 2010, os dados mostram que, nessas coortes de idade (45 a 54 anos), as diferenças diminuíram, porém o percentual de vítimas continuou sendo alto, sobretudo para os negros. É interessante notar que, no caso das vítimas de injúria por preconceito, os brancos estão mais bem representados percentualmente nas coortes de idade mais velha, de 55 a 64 anos, e 60 anos e mais de idade entre os anos de 2007 e 2010 (Tabela 1). Nesse caso, a hipótese mais provável é que os crimes de injúria por preconceito, denunciados por brancos, tenham correlação com a idade da vítima. 
Tabela 1 - Vítima segundo a cor e idade entre os anos de 2007-2010 (\% na linha)

\begin{tabular}{|c|c|c|c|c|}
\hline \multirow{2}{*}{ Ano } & \multirow{2}{*}{ Idade } & \multicolumn{3}{|c|}{ Cor } \\
\hline & & Branca & Negra & Parda \\
\hline \multirow{7}{*}{2007} & 0 a 14 & 3,1 & 71,9 & 25,0 \\
\hline & 15 a 24 & 8,3 & 65,3 & 26,4 \\
\hline & 25 a 34 & 6,5 & 66,8 & 26,7 \\
\hline & 35 a 44 & 9,9 & 60,2 & 29,8 \\
\hline & 45 a 54 & 8,2 & 74,5 & 17,3 \\
\hline & 55 a 64 & 11,1 & 61,1 & 27,8 \\
\hline & $65+$ & 26,7 & 53,3 & 20,0 \\
\hline \multirow{7}{*}{2008} & 0 a 14 & 6,3 & 62,5 & 31,3 \\
\hline & 15 a 24 & 6,4 & 66,4 & 27,1 \\
\hline & 25 a 34 & 9,5 & 67,6 & 22,9 \\
\hline & 35 a 44 & 12,4 & 66,0 & 21,6 \\
\hline & 45 a 54 & 9,9 & 68,3 & 21,8 \\
\hline & 55 a 64 & 22,0 & 48,0 & 30,0 \\
\hline & $65+$ & 26,9 & 50,0 & 23,1 \\
\hline \multirow{7}{*}{2009} & 0 a 14 & 8,6 & 51,7 & 39,7 \\
\hline & 15 a 24 & 12,4 & 51,6 & 36,0 \\
\hline & 25 a 34 & 12,4 & 65,2 & 22,4 \\
\hline & 35 a 44 & 17,7 & 62,5 & 19,8 \\
\hline & 45 a 54 & 19,8 & 56,3 & 24,0 \\
\hline & 55 a 64 & 29,1 & 44,3 & 26,6 \\
\hline & $65+$ & 34,5 & 58,6 & 6,9 \\
\hline \multirow{7}{*}{2010} & 0 a 14 & 5,6 & 61,1 & 33,3 \\
\hline & 15 a 24 & 7,0 & 69,3 & 23,6 \\
\hline & 25 a 34 & 9,9 & 64,6 & 25,5 \\
\hline & 35 a 44 & 10,3 & 59,9 & 29,8 \\
\hline & 45 a 54 & 19,0 & 62,1 & 19,0 \\
\hline & 55 a 64 & 20,5 & 65,4 & 14,1 \\
\hline & $65+$ & 38,3 & 42,6 & 19,1 \\
\hline
\end{tabular}

Fonte: ISP. Tabulado pelas autoras.

Com relação à escolaridade da vítima de injúria por preconceito, observamos que na Tabela 2 temos percentualmente mais negros e pardos com 5 a 8 e 9 a 11 anos de escolaridade, enquanto os brancos estão em um 
nível escolar bem mais avançado, perfazendo 9 e 11 e 12 anos e mais de escolaridade entre os anos de 2007 e 2010.

Tabela 2 - Vítima segundo a cor e a escolaridade entre os anos de 2007-2010 (\% na coluna)

\begin{tabular}{|c|c|c|c|c|}
\hline \multirow{2}{*}{ Ano } & \multirow{2}{*}{ Escolaridade } & \multicolumn{3}{|c|}{ Cor } \\
\hline & & Branca & Negra & Parda \\
\hline \multirow{5}{*}{2007} & 5 a 8 anos & 27,3 & 42,9 & 38,2 \\
\hline & 9 e 11 anos & 34,5 & 39,7 & 39,4 \\
\hline & 12 anos e mais & 38,2 & 14,7 & 20,0 \\
\hline & Alfabetizado & 0,0 & 1,8 & 0,6 \\
\hline & Analfabeto & 0,0 & 0,9 & 1,8 \\
\hline \multirow{5}{*}{2008} & 5 a 8 anos & 33,3 & 46,7 & 30,6 \\
\hline & 9 e 11 anos & 29,8 & 40,8 & 43,4 \\
\hline & 12 anos e mais & 35,7 & 9,7 & 24,3 \\
\hline & Alfabetizado & 1,2 & 1,6 & 0,6 \\
\hline & Analfabeto & 0,0 & 1,2 & 1,2 \\
\hline \multirow{5}{*}{2009} & 5 a 8 anos & 25,5 & 43,8 & 34,3 \\
\hline & 9 e 11 anos & 35,2 & 41,9 & 43,0 \\
\hline & 12 anos e mais & 34,5 & 12,1 & 18,6 \\
\hline & Alfabetizado & 3,0 & 1,2 & 2,9 \\
\hline & Analfabeto & 1,8 & 1,0 & 1,2 \\
\hline \multirow{5}{*}{2010} & 5 a 8 anos & 23,7 & 44,5 & 38,6 \\
\hline & 9 e 11 anos & 40,0 & 42,7 & 38,6 \\
\hline & 12 anos e mais & 31,9 & 10,7 & 19,1 \\
\hline & Alfabetizado & 3,0 & 1,2 & 2,8 \\
\hline & Analfabeto & 1,5 & 0,9 & 0,8 \\
\hline
\end{tabular}

Fonte: ISP. Tabulado pelas autoras.

O dado sobre a escolaridade, como visto na Tabela 2, das vítimas de injúria por preconceito é interessante tendo em vista que, quando observamos a Tabela 3, logo constatamos que o nível de escolaridade, sobretudo de negros, que é baixa, está correlacionado ao tipo de ocupação exercido por eles no mercado de trabalho. De acordo com a nossa distribuição ocupacional, observamos que em torno de $24 \%$ das vítimas de cor negra estavam trabalhando em ocupações no manual não qualificado, entre os anos de 2007-2009 (em 2010 caiu para 22\%), relacionadas, sobretudo, aos serviços 
braçais, domésticos e mal definidos. Outras vítimas de cor negra, em torno de $20 \%$, estavam nas ocupações no não manual de rotina, relacionadas a cargos em escritório, trabalhadores religiosos, vendedores, oficiais de justiça e trabalhadores na educação (Tabela 3).

Os pardos vítimas também se encontravam percentualmente bem representados nas categorias ocupacionais não manuais de rotina e no manual não qualificado, apesar da oscilação dos resultados percentuais, em cada ano, sobre o número de vítimas nesse grupo, enquanto os brancos vítimas de injúria por preconceito encontravam-se representados percentualmente entre os profissionais e administradores (diretores, gerentes, executivos etc.) e não manual de rotina. Chama-se atenção, porém, para o fato de que os percentuais na categoria aposentados e pensionistas, no grupo de vítimas brancas, ao longo dos anos de 2007-2010, aumentou (em 2007 era 3,3\% e, em 2010, passou a ser 15,8\%), assim seguimos com mais evidências de que crimes de injúria por preconceito podem estar correlacionados à idade para esse grupo de cor branca.

Tabela 3 - Vítima segundo a cor e ocupação entre os anos de 2007-2010 (\% na coluna)

\begin{tabular}{|c|c|c|c|c|}
\hline \multirow{2}{*}{ Ano } & \multirow{2}{*}{ Ocupação } & \multicolumn{3}{|c|}{ Cor } \\
\hline & & Branca & Negra & Parda \\
\hline \multirow{12}{*}{2007} & Profissionais e administradores & 21,7 & 6,0 & 13,8 \\
\hline & Não manual de rotina & 25,0 & 19,2 & 21,3 \\
\hline & Pequenos proprietários & 5,0 & 2,6 & 3,2 \\
\hline & Autônomos & 3,3 & 2,4 & 2,7 \\
\hline & Trabalhadores do manual qualificado & 5,0 & 10,3 & 5,3 \\
\hline & Trabalho manual não qualificado & 13,3 & 24,6 & 19,7 \\
\hline & Trabalho rural & 0,0 & 0,2 & 0,0 \\
\hline & Aposentados e pensionistas & 3,3 & 2,8 & 3,2 \\
\hline & Estudantes & 6,7 & 8,1 & 12,8 \\
\hline & Desempregados & 8,3 & 12,4 & 6,9 \\
\hline & Ignorado & 5,0 & 3,6 & 4,8 \\
\hline & Outros & 3,3 & 7,9 & 6,4 \\
\hline
\end{tabular}




\begin{tabular}{|c|c|c|c|c|}
\hline \multirow{2}{*}{ Ano } & \multirow{2}{*}{ Ocupação } & \multicolumn{3}{|c|}{ Cor } \\
\hline & & Branca & Negra & Parda \\
\hline \multirow{12}{*}{2008} & Profissionais e administradores & 18,5 & 5,3 & 13,1 \\
\hline & Não manual de rotina & 13,0 & 19,5 & 16,7 \\
\hline & Pequenos proprietários & 3,3 & 1,1 & 1,0 \\
\hline & Autônomos & 6,5 & 2,6 & 1,0 \\
\hline & Trabalhadores do manual qualificado & 6,5 & 9,9 & 11,6 \\
\hline & Trabalho manual não qualificado & 13,0 & 24,9 & 13,1 \\
\hline & Trabalho rural & 0,0 & 0,4 & 0,0 \\
\hline & Aposentados e pensionistas & 8,7 & 4,4 & 7,1 \\
\hline & Estudantes & 7,6 & 7,4 & 8,6 \\
\hline & Desempregados & 12,0 & 13,3 & 16,7 \\
\hline & Ignorado & 3,3 & 3,3 & 7,6 \\
\hline & Outros & 7,6 & 7,9 & 3,5 \\
\hline \multirow{12}{*}{2009} & Profissionais e administradores & 17,8 & 6,1 & 11,7 \\
\hline & Não manual de rotina & 14,4 & 22,3 & 21,2 \\
\hline & Pequenos proprietários & 6,9 & 1,6 & 3,0 \\
\hline & Autônomos & 2,3 & 2,1 & 2,7 \\
\hline & Trabalhadores do manual qualificado & 7,5 & 10,7 & 8,3 \\
\hline & Trabalho manual não qualificado & 12,1 & 24,9 & 13,3 \\
\hline & Trabalho rural & 0,0 & 0,2 & 0,4 \\
\hline & Aposentados e pensionistas & 10,9 & 2,9 & 4,2 \\
\hline & Estudantes & 8,0 & 8,4 & 13,3 \\
\hline & Desempregados & 10,3 & 10,5 & 13,3 \\
\hline & Ignorado & 4,0 & 2,4 & 2,7 \\
\hline & Outros & 5,7 & 7,8 & 6,1 \\
\hline \multirow{12}{*}{2010} & Profissionais e administradores & 17,8 & 5,0 & 5,9 \\
\hline & Não manual de rotina & 12,3 & 20,2 & 16,0 \\
\hline & Pequenos proprietários & 6,2 & 1,6 & 3,1 \\
\hline & Autônomos & 2,7 & 1,1 & 3,1 \\
\hline & Trabalhadores do manual qualificado & 6,8 & 10,2 & 5,6 \\
\hline & Trabalho manual não qualificado & 7,5 & 22,9 & 19,1 \\
\hline & Trabalho rural & 0,0 & 0,4 & 0,3 \\
\hline & Aposentados e pensionistas & 15,8 & 4,6 & 3,8 \\
\hline & Estudantes & 7,5 & 10,1 & 13,5 \\
\hline & Desempregados & 13,0 & 10,9 & 13,5 \\
\hline & Ignorado & 4,1 & 4,9 & 8,3 \\
\hline & Outros & 6,2 & 8,0 & 7,6 \\
\hline
\end{tabular}

Fonte: ISP. Tabulado pelas autoras. 
As figuras 1, 2, 3 e 4 são resultado de uma análise de correspondência (AC), cuja técnica de análise exploratória de dados é adequada para estudar as relações e semelhanças existentes entre: a) as categorias de linhas e as categorias de colunas de uma tabela de contingência, e b) o conjunto de categorias de linhas e o conjunto categorias de colunas. A AC mostra como as variáveis dispostas em linhas e colunas estão relacionadas e não somente se a relação existe (GREENACRE et al., 1987). Apesar de ser uma técnica descritiva e exploratória, a AC ajuda a simplificar dados complexos, produzindo análises exaustivas de informações que suportam conclusões interessantes, como veremos neste estudo.

Nesse sentido, as figuras mostram a relação entre o local de ocorrência do delito e a cor segundo o sexo, nos anos de 2007 e 2010, no Estado do Rio de Janeiro. Com relação ao local de ocorrência, podemos observar a existência de três grandes grupos de incidência dos crimes de injúria por preconceito. Temos os "Locais Públicos", que compreendem aeroportos, estacionamentos, embarcações, estabelecimentos comerciais, hospitais etc. A categoria "Residências" pode ser o local de moradia da vítima ou de trabalho, e "Outros" são locais descritos no banco de dados como lan houses, cabeleireiro, lanchonetes, bancos etc.

Segundo o exercício proposto de análise de correspondência, entre as categorias cor e local onde ocorreram os crimes de injúria por preconceito, as figuras 1 e 2 mostram que há uma proximidade muito grande entre as ocorrências de tais crimes em "Locais Públicos" e "Residências" a vítimas mulheres negras e pardas, se comparadas a mulheres brancas nos anos de 2007 e 2010. Em outras palavras, há uma heterogeneidade entre as colunas, sendo que negros e pardos apresentam ocorrências relativamente homogêneas. 
Figura 1 - Mulheres vítimas segundo local de ocorrência do delito e cor em 2007

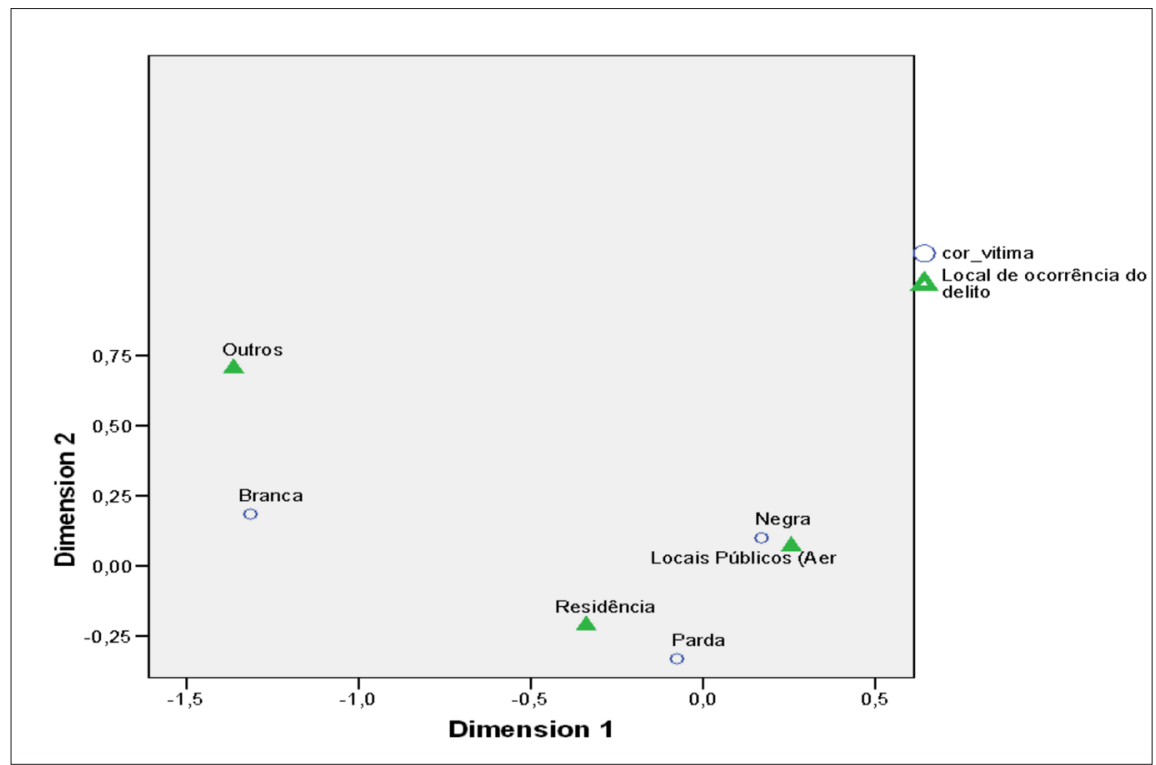

Fonte: ISP. Tabulado pelas autoras.

Figura 2 - Mulheres vítimas segundo local de ocorrência do delito e cor em 2010

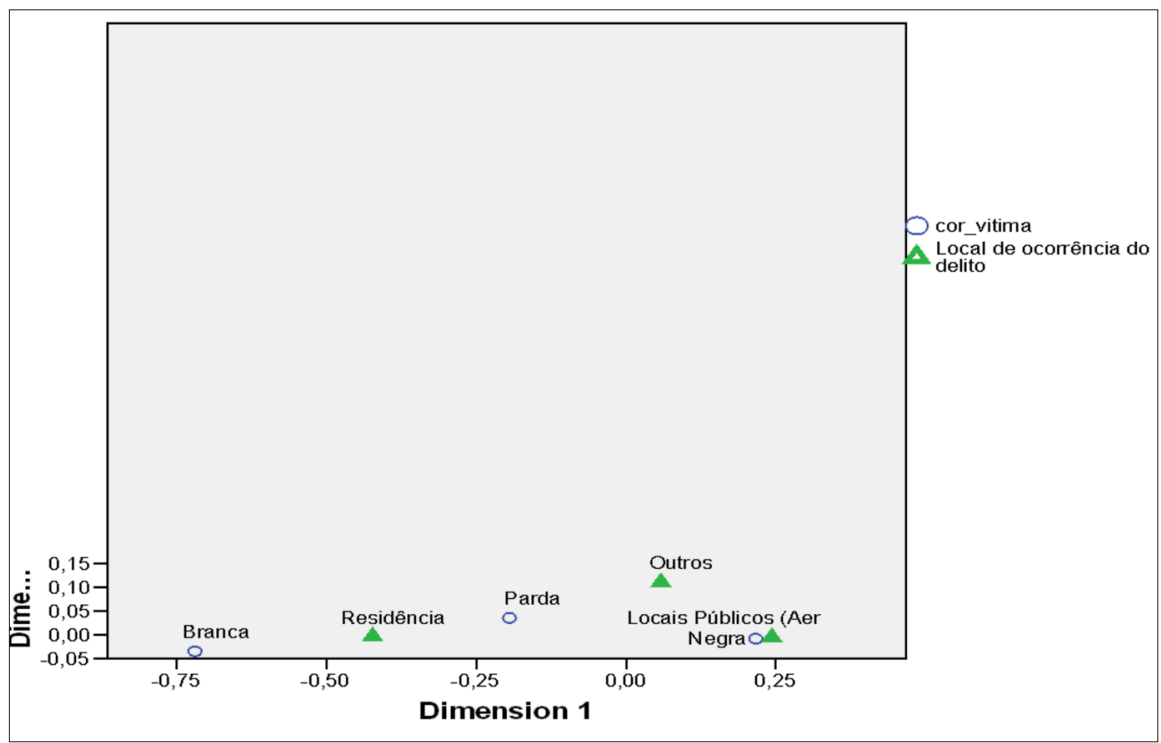

Fonte: ISP. Tabulado pelas autoras. 
A Figura 3 mostra que, em 2007, tem-se uma proximidade das ocorrências de crimes de injúria por preconceito a "Locais Públicos", quando relacionados a vítimas homens negros e pardos e se comparados a homens brancos. As vítimas, neste caso, apresentaram uma heterogeneidade relativa em relação às ocorrências, sendo que negros e pardos agregaram ocorrências relativamente mais homogêneas no referido ano.

Figura 3 - Homens vítimas segundo local de ocorrência do delito e cor em 2007

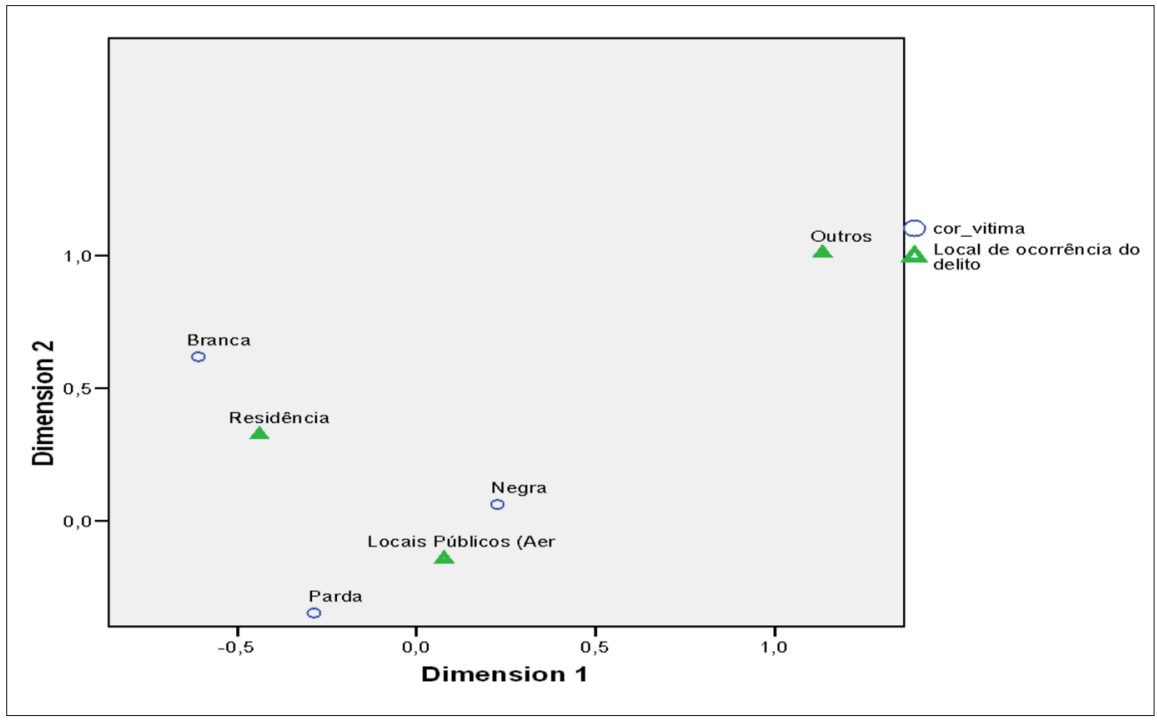

Fonte: ISP. Tabulado pelas autoras.

Já na figura 4 podemos observar uma pequena mudança nos resultados da AC para 2010. Observa-se que a proximidade das ocorrências de crimes de injúria por preconceito a "Locais Públicos" só estava relacionada a vítimas homens e negros, enquanto os pardos se aproximavam de ocorrências nas "Residências". Segundo esse resultado, as vítimas continuaram apresentando uma heterogeneidade relativa em relação às ocorrências. 
Figura 4 - Homens vítimas segundo local de ocorrência do delito e cor em 2010

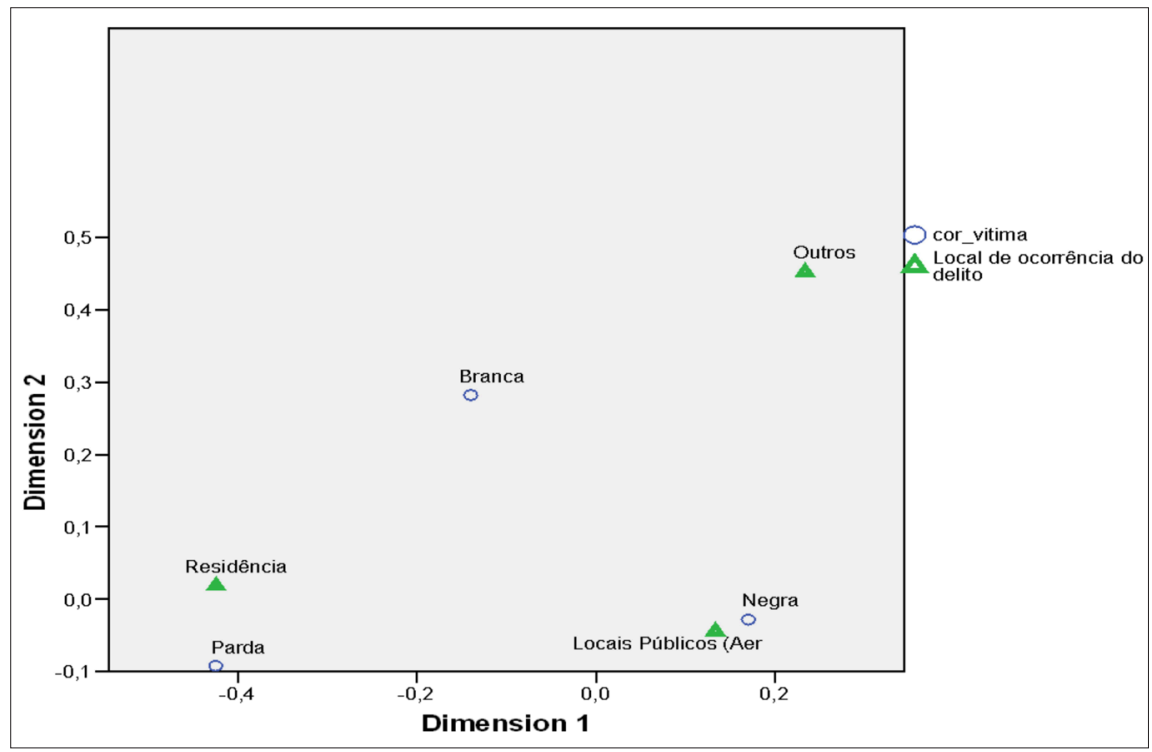

Fonte: ISP. Tabulado pelas autoras.

As figuras 5, 6, 7 e 8 são resultados também de uma análise de correspondência (AC) e mostram a relação do agressor com a vítima de injúria por preconceito no Estado do Rio de Janeiro. Para compreender melhor o dado, organizamos categorias que permitissem um melhor reconhecimento na relação entre vítima e agressor. Nesse sentido, foram considerados na categoria "cônjuge" os casais, casados ou declarados no registro como união consensual; na categoria "familiar", temos primos, pais, irmãos etc.; na categoria "Ex-relacionamento", foram incluídos ex-companheiro, exnamorado, ex-noivo etc.; os casos "Extrafamiliares" foram relacionados a amigos e vizinhos; a categoria "Trabalho" a chefe, cliente, colega etc., e a categoria "Nenhuma" está relacionada ao fato de que a vítima não conhecia o seu agressor.

As figuras 5 e 6 mostram a relação que as mulheres vítimas de injúria por preconceito tinham com seu agressor em 2007 e 2010. As mulheres negras e pardas, nos referidos anos, estavam muito próximas na maioria das categorias de agressores, exceto no que diz respeito ao "Cônjuge", e apresentaram uma maior homogeneidade em termos de comportamento no conjunto dos seus resultados se comparados com as mulheres brancas. 
Figura 5 - Mulheres vítimas segundo relação com o envolvido na agressão em categorias e cor em 2007

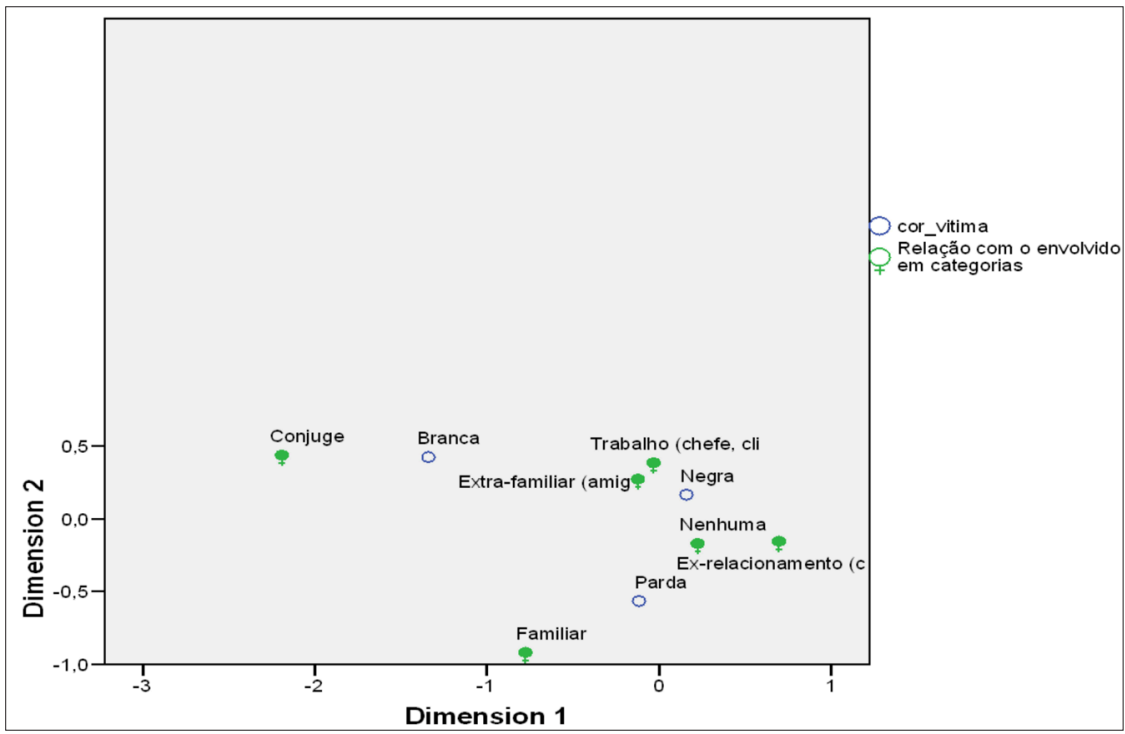

Fonte: ISP. Tabulado pelas autoras.

Figura 6 - Mulheres vítimas segundo relação com o envolvido na agressão em categorias e cor em 2010

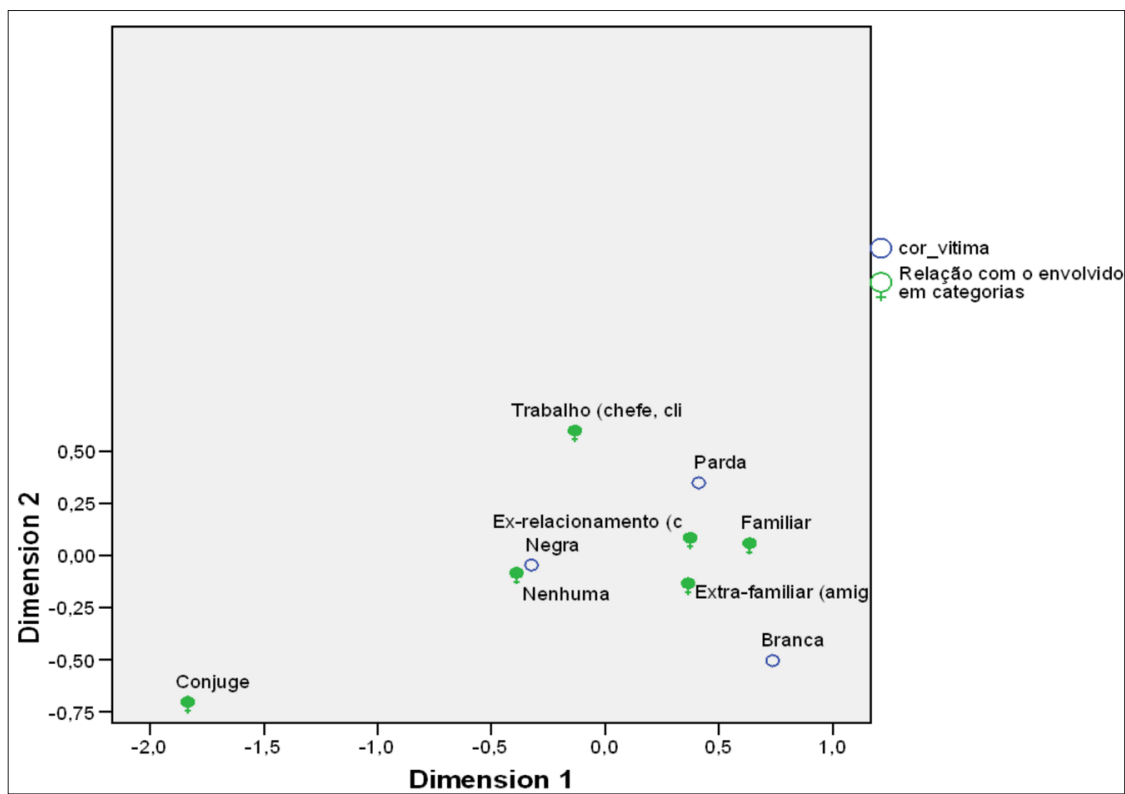

Fonte: ISP. Tabulado pelas autoras. 
Já nas figuras 7 e 8 temos, nos anos de 2007 e 2010, um comportamento um pouco diferente na relação vítima e agressor em relação aos homens. Os grupos de cor são bastante heterogêneos no que diz respeito ao tipo de agressor nos referidos anos. Em 2007 e 2010, os homens negros vítimas de injúria por preconceito estavam muito mais próximos de agressores no "Trabalho" e quando não havia "Nenhum" relacionamento com esse agressor. Os pardos vítimas estavam muito mais próximos ao agressor "Familiar" em 2007, e em 2010 próximos aos agressores "Familiares" e "Extrafamiliares", enquanto os brancos estavam mais relacionados aos agressores "Extrafamiliares" em 2007, e em 2010 apenas "familiares".

Figura 7 - Homens vítimas segundo relação com o envolvido na agressão em categorias e cor em 2007

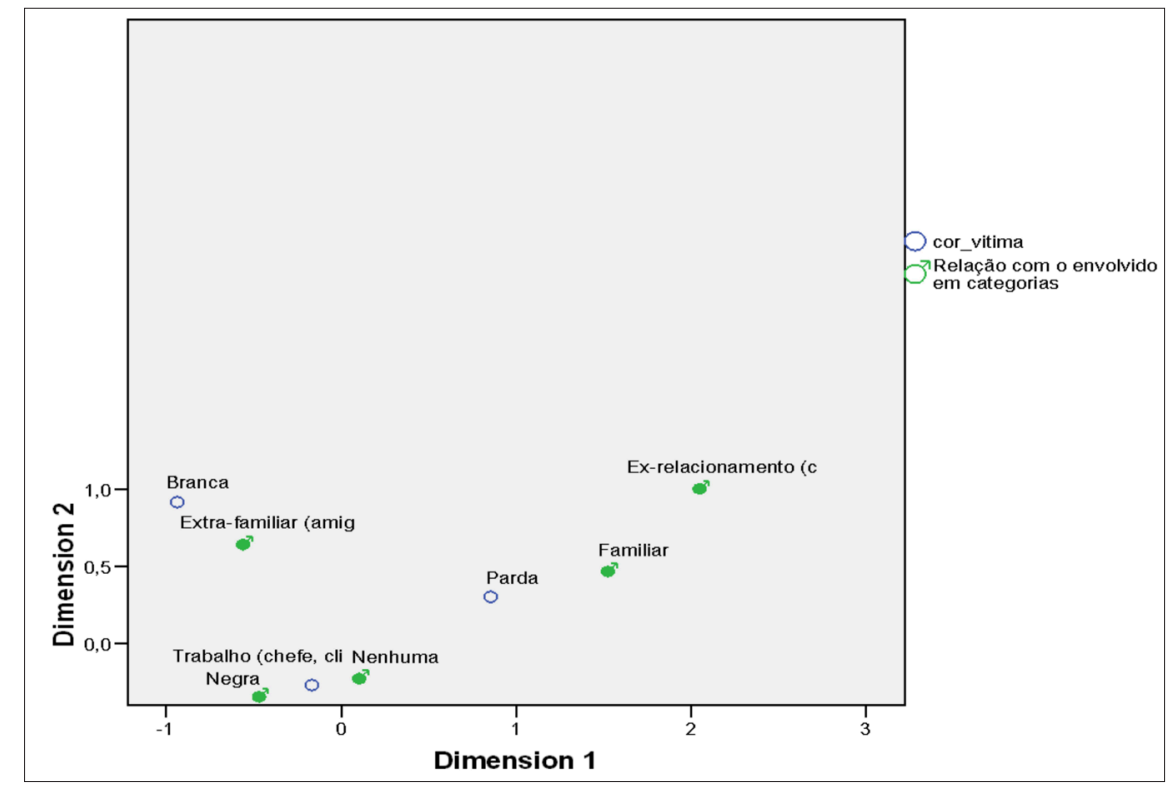

Fonte: ISP. Tabulado pelas autoras. 
Figura 8 - Homens vítimas segundo relação com o envolvido na agressão em categorias e cor em 2010

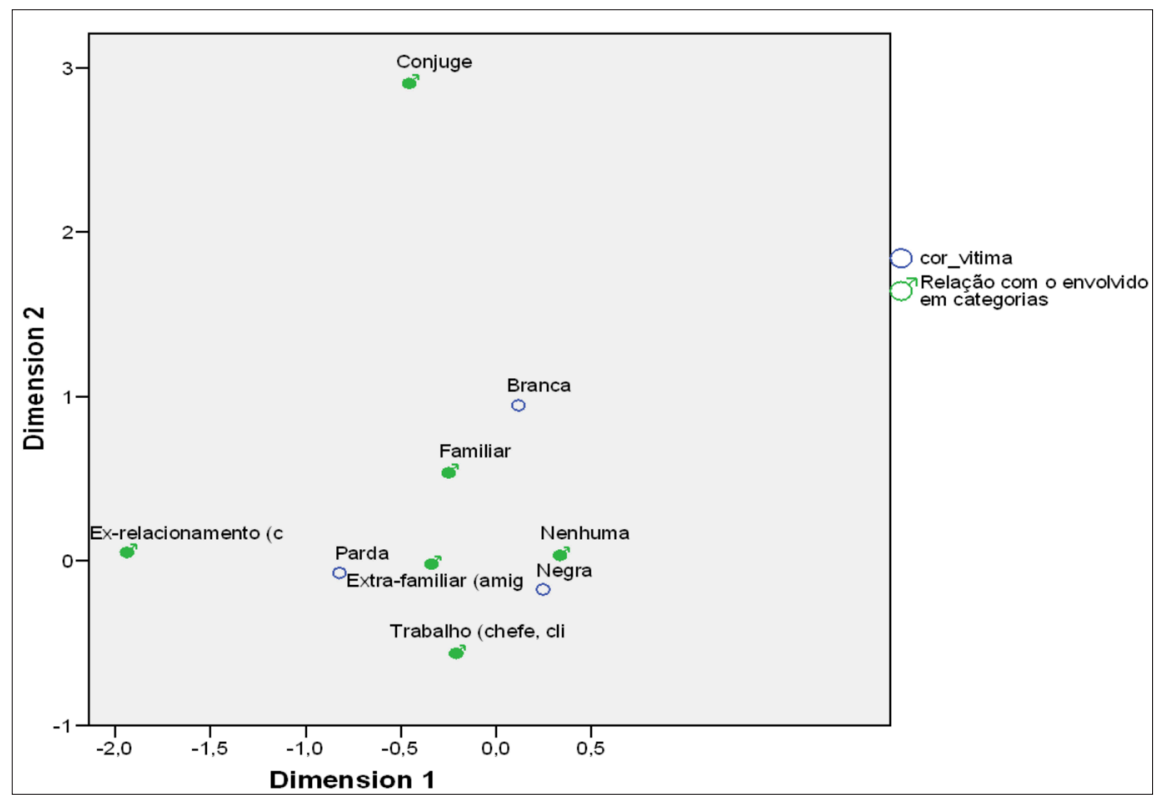

Fonte: ISP. Tabulado pelas autoras.

É importante observar que a categoria "nenhuma" tem uma proximidade muito grande da mulher e do homem negro vítima de injúria por preconceito nas figuras 5, 6, 7 e 8. Isso indica que os insultos são proferidos em ambientes por onde passam pessoas que não são do convívio da vítima, ou seja, a frequência maior dos insultos é nos "Locais Públicos", como observamos nas figuras 1, 2, 3 e 4.

É interessante evidenciar que há um farto material estatístico que comprova que os brasileiros de cor não branca estão flagrantemente inferiorizados em termos econômicos em relação aos brancos e, muitas vezes, caímos na armadilha do racismo ao tratar apenas das desigualdades como um fator socioeconômico. Mas não há como negar, pelo que vimos observando nos dados, que a discriminação existe, e no mínimo ajuda a perpetuar uma situação já centenária de desigualdade racial.

É relevante que se pesquisem situações cotidianas que levem em conta a classificação de cor/raça feita pelo próprio agente social, uma vez que existem no Brasil diferentes sistemas classificatórios. Se, no momento de responder sobre sua cor, o censo do IBGE oferece um continuum que vai do preto ao branco (e desde 1991, o indígena), no cotidiano as respostas 
à mesma questão oferecem matizes mais variados. Essa variação comporta diferenças regionais, afetivas e composições que alcançam uma escala que pode incluir o branco-azedo, moreno-claro, moreno-escuro, marrom até o azul.

A mudança que ocorre com a lei 7.716 da Constituição de 1988 é o reconhecimento, em forma de registro, da forma de classificação adotada pelo Movimento Negro². Isto quer dizer que, no momento do registro em uma delegacia, o denunciante está assumindo publicamente (e por que não politicamente, nos moldes de um conflito mais aberto?) que sua cor/raça não é um meio de caminho entre o preto e o branco. Ao invés do afastamento do grupo racial historicamente tratado como uma minoria (demonstrado na autoclassificação como moreno e suas variações), o registro possibilita que se repense como, a partir de classificações arbitrárias quanto à cor, determinadas políticas públicas foram implementadas visando à administração desses grupos. E que o momento atual, após a criminalização, apresenta, a partir de uma reclassificação quanto à cor, uma abertura de novas possibilidades de pesquisa sobre as relações raciais no Brasil, uma vez que a forma de classificação do Movimento Negro torna-se a principal referência no momento do registro em delegacias.

Desde que a lei foi promulgada, casos de racismo no Brasil passaram a ter suas queixas registradas em delegacias. Em alguns casos, esse primeiro momento já seria o primeiro filtro de impedimento do registro, uma vez que o entendimento vigente tanto no Judiciário como entre os operadores do Direito é de que, sendo "fatos isolados, não constituem racismo, que aliás inexiste no Brasil". Essa observação leva a crer que um número muito maior de casos não é sequer registrado já que, no momento da interação, entre o denunciante e a lei, os capitais linguísticos próprios do campo jurídico levam à desconstrução do ato de ofensa racista. Outro problema frequente: a presença de testemunhas, uma vez que raramente existem no Brasil situações abertamente racistas, como placas com impedimento de entrada em clubes ou locais de lazer. Se os casos ocorrem em espaços como trabalho, consumo, vizinhança ou via pública, geralmente existem outras pessoas que

\footnotetext{
${ }^{2} \mathrm{O}$ movimento negro há muito tempo utiliza um terceiro sistema classificatório que agora se tornou amplamente aceito pela mídia, pelos formuladores de políticas públicas e acadêmicos. Esse sistema de classificação usa apenas dois termos: negro e branco. Esse sistema é definido como sendo um sistema político, uma vez que é amplamente utilizado pelo governo, pela mídia, em artigos acadêmicos, mas raramente utilizado no discurso popular (TELLES, 2003, p.100).
} 
os presenciam. Mas envolver-se como testemunha configura engajamento nem sempre desejável (SILVA, 2003).

\section{Tudo vai bem porque não está tão ruim quanto no Deep South... Não?}

Finalizar este trabalho citando uma expressão empregada por Costa Pinto (1953) na sua pesquisa no Rio de Janeiro, na década de 50, tem um objetivo: à época o pesquisador tinha como uma de suas principais preocupações a metodologia que possibilitaria a compreensão das tensões raciais entre brancos e negros no Brasil. A pesquisa Unesco marcou os estudos sobre relações raciais no Brasil não só pela demonstração inequívoca dessas tensões em diferentes cidades brasileiras como também pelo emprego de técnicas de pesquisa rigorosas tendo como resultado uma contribuição definitiva das ciências sociais para mudança de paradigmas nas interpretações sobre a vida material e espiritual do negro no país. Retomando os termos de Costa Pinto, o Rio de Janeiro era, naquele momento, "uma sociedade em mudança”. Um dos aspectos que podem ser destacados em sua pesquisa são as consequências da inserção do negro em uma sociedade competitiva e em processo de urbanização. Como ele afirma:

"O padrão social anterior, do qual estamos historicamente nos
afastando, e que se caracterizou pela subalternização econômica,
jurídica e psicológica da população de cor em todos os planos da
vida nacional, só podia ser apontado como livre de preconceitos,
porque dentro dele, o preconceito não tinha uma função definida
na defesa de determinadas posições sociais, já que estas não
estavam, ou não se sentiam, ameaçadas pela mobilidade social
dos elementos de cor que era praticamente nula (PINTO, 1953,
p.177)".

É nesse processo de mudança social que a organização do movimento negro, em diálogo com pesquisas críticas à visão freyriana de integração racial harmoniosa, insere uma importante brecha no sistema classificatório brasileiro: a polaridade branco/negro. O pensamento de Gilberto Freyre, avançado para a época, não mostrava que a dinâmica desse processo de miscigenação se encontrava menos na "lubricidade" dos portugueses e seus descendentes, e na real ou suposta "indiferença” dos brasileiros em relação 
aos critérios raciais habituais, e mais na exploração sexual exercida sobre as mulheres negras (ALENCASTRO apud D’ADESKY, 1998, p.78).

O esforço realizado aqui demonstra que, dos 3.773 registros feitos no Rio de Janeiro entre 2007-2010, a maioria foi feita como injúria por preconceito, e o grupo racial atingido foram negros e pardos. Um dos resultados que mais merece atenção demonstra que boa parte das ocupações dos denunciantes pode ser classificada como ocupações de baixa qualificação. Podemos inferir daí que os insultos ocorrem em relações no espaço público, como fica demonstrado nas figuras 1, 2, 3 e 4. É provável que parte deles ocorra em situações de trabalho, e cabe retomar a argumentação de Costa Pinto (1953) sobre a função do preconceito em uma sociedade em mudança. Não aceitar que determinadas formas de tratamento sejam dispensadas a um indivíduo em função da sua cor poderia produzir tensões sociais que acabam desaguando no sistema de justiça. Como uma demonstração inequívoca da não aceitação da desconsideração (CARDOSO DE OLIVEIRA, 2008), os registros constituem importante indicador dos atuais casos de racismo no Brasil. Ao mesmo tempo, é preciso que pesquisas foquem esse momento em que o conflito instaura uma dinâmica inexistente antes de Constituição de 1988: onde se altera o estatuto de cidadania de um grupo historicamente inserido nas Constituições brasileiras como ferramenta para acumulação material ou então como elemento indesejado na melhoria racial. No ano de 2012, completamos exatamente 101 anos da declaração de João Baptista Lacerda sobre o destino do negro no Brasil: em sua apresentação no I Congresso Mundial das Raças, demonstrava uma das principais formas de resolução do problema dos africanos no Brasil: o embranquecimento sucessivo da população. Em 100 anos, segundo o antropólogo, não haveria mais negros no Brasil.

Não só a raça "persiste" como vivemos um momento especialmente tenso (nos termos de Costa Pinto) para pensar a interação entre brancos e não brancos. Os casos de racismo apresentados são parte desse processo de mudança nas formas de classificação quanto à cor. $O$ exemplo que melhor tipifica as atuais mudanças são as ações afirmativas nas universidades brasileiras. Como afirma Feres (2008), a reparação no Brasil é frequentemente empregada quando o tema é corrigir os erros cometidos contra os negros e afrodescendentes ao longo da história do país. No atual cenário de reconhecimento da cor/raça, enquanto forma de acesso à universidade, como condição para uso e permanência na terra (quilombolas) e enquanto critério para estabelecimento de ações indenizatórias por preconceito, as 
pesquisas sobre relações raciais no Brasil são imprescindíveis, pois possibilitam uma reflexão sobre essa complexa relação entre lei, cidadania e raça em nosso país.

\section{Referências}

BARBOSA, Fábio Feliciano.

(2011). Caso Simone A Diniz, a falta de acesso a justiça para as vítimas de crimes raciais da lei Caó. Revista de Estudos Jurídicos, São Paulo, v.15, n²2, p.119-146.

CABRAL, Paulo Eduardo.

(1970). 0 negro na Constituição de 1824. Revista de Informação Legislativa, Brasília, v.11, n 41, p. 127-164, jan./mar. de 1974.

D'ADESK, Jacques.

(1998). Racismos e anti-racismos no Brasil. Estudos Afro-Asiáticos, Rio de Janeiro, n 33, p.71-87.

FERES JÚNIOR, João.

(2008). Ação Afirmativa, Política Pública e Opinião. Sinais Sociais, Rio de Janeiro, vol 3, n० 8, p.38-77.

FERNANDES, Florestan.

(1965). A integração do negro na sociedade de classes. São Paulo: Nacional.

FREYRE, Gilberto.

(1933). Casa-Grande \& Senzala: formação da família brasileira sob o regime da economia patriarcal. Rio de Janeiro: Schimidt.

GERALD0, Endrica.

(2009). A lei de cotas de 1934: controle de estrangeiros no Brasil. Cadernos AEL, vol 15, $n^{\circ} 27$, p.171-212.

GREENACRE, M; HASTIE, T.

(1987). The geometric interpretation of correspondence analysis. Journal of the American Statistical Association, v. 82, issue 398, p.437-447.
GUIMARÃES, Sérgio Alfredo Antonio.

(2002). Classes, raças e democracia. São Paulo: Editora 34.

GUIMARÃES, Sérgio Alfredo Antonio.

(1999). Racismo e Anti-racismo no Brasil. São Paulo: editora 34.

HANCHARD, Michael George.

(2001). Orfeu e o Poder, movimento negro no Rio e São Paulo (1945-1988). Rio de Janeiro: EdUerj.

HASENBALG, Carlos, SILVA. Nelson do Valle.

(1992). Relações raciais no Brasil contemporâneo. Rio de Janeiro: Rio Fundo Editora.

(1988). Estrutura Social, Mobilidade e Raça, Rio de Janeiro, Iuperj.

HASENBALG, Carlos.

(1979). Discriminação e desigualdades raciais no Brasil. Rio de Janeiro: Graal.

HOLANDA, Sérgio Buarque de.

(1963). Raízes do Brasil, Brasília: Editora da Universidade de Brasília, 4a Edição.

MAIO, Marcos Chor.

(1997). Uma polêmica esquecida: Costa Pinto, Guerreiro Ramos e o tema das relações raciais, Dados, Rio de Janeiro, v. 40, nº 1, p.127-162.

MOTTA, Roberto.

(2000). Paradigmas de interpretação das relações raciais no Brasil. Estudos AfroAsiáticos, Rio de Janeiro, n. 38, p.113-127.

NOGUEIRA, Oracy.

(1985). Tanto preto quanto branco: estudos de relações raciais. São Paulo: T. A. Queiroz. 
PAIXÃ0, Marcelo.

(2000). Desenvolvimento Humano e as Desigualdades Étnicas no Brasil: um retrato de final de século, Revista Proposta, n 86, ano XXIX, Novembro de 2000, p.30-51.

OLIVEIRA, Luis Roberto Cardoso de.

(2008). Existe violência sem agressão moral?. Revista Brasileira de Ciências Sociais, v. 23, nº 67, junho/2008, p.135-196.

PAGER, Devah.

(2006). Medir a Discriminação, Tempo Social, v. 18 , n² 2, São Paulo, p.65-98.

PINT0, Luiz Aguiar da Costa.

(1998). O Negro no Rio de Janeiro: Relações de Raça numa sociedade em mudança. 2. ed. Rio de Janeiro: Ed. da UFRJ.

RODRIGUES, Nina.

(1938). As Raças humanas e a responsabilidade penal no Brasil. Rio de Janeiro: Nacional.

SCWHARCZ, Lília Moritz; QUEIROZ, Renato da Silva (Orgs.).

(1996). Raça e diversidade. São Paulo: Edusp.

SILVA JÚNIOR, Hédio.

(2000). Do racismo legal ao princípio da ação afirmativa: a lei como obstáculo e como instrumento dos direitos e interesses do povo negro. In: Antonio Sérgio Alfredo Guimarães; Lynn Huntley (Orgs.); Tirando a máscara: ensaios sobre o racismo no Brasil. São Paulo: Paz e Terra, p.359-387.
SILVA, Katia Elenise Oliveira da.

(2001).Opapeldo direito penal no enfrentamento da discriminação. Porto Alegre: Livraria do Advogado.

SILVA, Luciane Soares da.

(2003). 0 cotidiano das relações inter-raciais: o processo de criminalização de atos decorrentes de preconceito de raça e cor no RS. Dissertação de Mestrado apresentada ao Programa de Pós-Graduação em Sociologia da Universidade Federal do Rio Grande do Sul UFRGS, Porto Alegre.

TELLES, Edward.

(2003). Racismo à Brasileira, uma nova perspectiva sociológica. Rio de Janeiro: Relume Dumará / Fundação Ford.

\section{Recebido em}

abril de 2014

\section{Aprovado em}

dezembro de 2014 